\title{
Phytochemical and Antioxidant Activities of Methanolic Extract of the Plant Euphorbia thymifolia Linn
}

Gurava Reddy $\mathbf{K}^{1^{*}}$, Anuradha $\mathbf{V}^{2}$ and Samba Siva Rao $\mathbf{V}^{3}$

${ }^{1}$ Department of Chemistry, Jawaharlal Nehru Technological University, Kakinada, Andhra Pradesh, India

${ }^{2}$ Department of Basic Science and Humanities, Vignan Nirulla Institute of Technology and Science for Women, Guntur, Andhra Pradesh, India

${ }^{3}$ Department of Chemistry, Government College (Autonomous), Rajahmundry, Andhra Pradesh, India

*Corresponding author: Gurava Reddy K, Department of Chemistry, Jawaharlal Nehru Technological University, Kakinada, Andhra Pradesh, India, Tel: 9100359251; Email: gkkvgreddy@gmail.com

Received: September 25, 2017; Accepted: October 05, 2017; Published: October 12, 2017

Copyright: ( 2017 Gurava Reddy K. This is an open-access article distributed under the terms of the Creative Commons Attribution License, which permits unrestricted use, distribution, and reproduction in any medium, provided the original author and source are credited.

\begin{abstract}
The present study was designed for phytochemical and antioxidant activity of methanolic extract of the whole plant Euphorbia thymifolia linn. Belonging to the family Euphorbiaceae. It cures many diseases. The phytochemicals present in this methanolic extract were studied by standard Protocols and the invitro antioxidant activities were studied using different methods i.e., $\mathrm{H}_{2} \mathrm{O}_{2}$ scavenging activity, Reducing power method and Phosphomolybdinum method. These three methods show significant activity with standard drugs.
\end{abstract}

Keywords: Euphorbia thymifolia linn.; Phytochemical screening; Antioxidant activities

\section{Introduction}

Euphorbia thymifolia linn. belongs to the family Euphorbiaceae. The plant is used as laxative, diuretic, antihelmintics, constipation, skin diseases, bitter and antiviral. Phytochemical screenings, antibacterial activity and Physico chemical constants of ethanolic extract of Euphorbia thymifolia linn. [1]. Review of literature did not reveal any information on studies of methanolic extract of this plant. Hence, in the basic present work in phytochemical screenings and antioxidant activities of the methanolic extract of whole plant of Euphorbia thymifolia Linn. was studied.

\section{Materials and Methods}

\section{Plant material}

The Whole parts of Euphorbia thymifolia linn. was collected from local areas of Anantapur and was identified and authenticated by Dr. Reddy Raju Venkatapathi Raju, Botanist, SK University, Anantapur, Andhra Pradesh, India. A voucher specimen has been preserved in our laboratory for future reference. The Whole plant was shade dried under reduced pressure, powdered by a mechanical grinder and were passed through 40-mesh sieve and stored in airtight container for further use.

\section{Preparation of extract}

About $1 \mathrm{~kg}$ of the powdered plant material was exhaustively extracted using Methanol solvent in a Soxhlet extractor. The extract was concentrated and dried by using Rotavapour (Heidolph) under vacuum. The yield of the concentrated Methanolic extract was $11.8 \%$.

\section{Preliminary phytochemical screening}

The crude drug was dissolved in distilled water and subjected to preliminary phytochemical screening. The study was carried out by using standard procedure described by Kokate [2] and Harborne [3].

\section{Scavenging of hydrogen peroxide}

A solution of $\mathrm{H}_{2} \mathrm{O}_{2}(20 \mathrm{~mm})$ was prepared in phosphate buffer saline (PBS, pH 7.4). Various concentration $(10 \mu \mathrm{g}-100 \mu \mathrm{g})$ of standard and extracts was prepared, $1 \mathrm{ml}$ of the extract and standard was dissolved in methanol in a separate volumetric flask and to this solution $2 \mathrm{ml}$ of $\mathrm{H}_{2} \mathrm{O}_{2}$ solution in PBS was added, the absorbance was measured at $230 \mathrm{~nm}$, after $10 \mathrm{~min}$ against blank solution. The \% inhibition of OD was calculated by the formula.

The percentage inhibition was calculated by using the formula.

\%inhibition $=\mathrm{A}_{\text {control }}-\mathrm{A}_{\text {sample }} / \mathrm{A}_{\text {control }} \times 100 \%$

\section{Determination of reducing power}

Method based on the principle of increase in the absorbance of the reaction mixture. Increase in the absorbance indicates increase in antioxidant activity [4]. Different concentration of extracts $(20 \mu \mathrm{g}-100 \mu \mathrm{g})$ in $1 \mathrm{ml}$ of distilled water were mixed with $2.5 \mathrm{ml}$ of phosphate buffer $(0.2 \mathrm{~m}$; pH 6.6$)$ and $2.5 \mathrm{ml}$ of potassium ferricyanide $\left[\mathrm{K}_{3} \mathrm{Fe}(\mathrm{CN})_{6}\right]$ $(1 \%)$, the resulting mixture was incubated at $50^{\circ} \mathrm{C}$ for half an hour. Then, $2.5 \mathrm{ml}$ of trichloroacetic acid (10\%) was added to the mixture, which was then centrifuged at $3000 \mathrm{rpm}$ for $10 \mathrm{~min}$. Finally, $2.5 \mathrm{ml}$ of upper layer solution was mixed with $2.5 \mathrm{ml}$ of distilled water and 0.5 $\mathrm{ml}$ of $\mathrm{FeCl}_{3}(0.1 \%)$ were added. The absorbance was measured at 700 $\mathrm{nm}$ in UV-Vis spectrophotometer against blank. Increasing of the reaction mixture indicates increasing reducing power [5]. The \% inhibition of OD was calculated by the formula.

The percentage inhibition was calculated by using the formula.

\%inhibition $=\mathrm{A}_{\text {control }}-\mathrm{A}_{\text {sample }} / \mathrm{A}_{\text {control }} \times 100 \%$ 


\section{Estimation of phosphomolybdenum}

In this method quantitative determination of anti-oxidant capacity, through the formation of phosphomolybdenum complex. The assay is based on the reduction of Mo (VI) to Mo (V) by the sample analyte and subsequent formation of a green phosphate Mo (V) complex at acidic $\mathrm{pH}$. An aliquot of $0.3 \mathrm{ml}$ of sample solution containing a reducing species in DMSO was combined in a test tube with $3 \mathrm{ml}$ of reagent solution $\left(0.6 \mathrm{~m} \mathrm{H}_{2} \mathrm{SO}_{4}, 28 \mathrm{~mm}\right.$ sodium phosphate and $4 \mathrm{~mm}$ ammonium molybdate) then the tubes were covered with aluminium foil and kept in a water bath at $95^{\circ} \mathrm{C}$ for $90 \mathrm{~min}$. Then the samples were cooled to room temperature, absorbance of each solution was measured at $695 \mathrm{~nm}$ against blank. The total anti-oxidant was expressed as mm equivalent to DMSO [6]. The \% inhibition of OD was calculated by the formula. The results are tabulated in Tables 2-4 and (Figures 1-3) respectively.

The percentage inhibition was calculated by using the formula.

$\%$ inhibition $=\mathrm{A}_{\text {control }}-\mathrm{A}_{\text {sample }} / \mathrm{A}_{\text {control }} \times 100 \%$

\section{Results and Discussion}

Phytochemical screening of Methanol extract of Euphorbia thymifolia linn. reveals the presence of Alkaloids, carbohydrates, glycosides, saponins and flavonoids as majorly compounds tabulated in Table 1. Antioxidant studies prove to show potent antioxidant activity for Methanol extract of Peristrophe paniculata Brummitt. Presence of the flavonoids in past reported to possess antioxidant properties [7]. Hydrogen peroxide scavenging Methanol, extract showed high activity, the reducing anti-oxidant activity shows the reducing property of the plant extracts on potassium ferricyanide. The absorbance is directly proportional to the reduction of ferric ions to ferrous ions, thus an increase in the absorbance denotes the reducing property of the plant extracts, Methanol extract show lesser antioxidant activity. In Phosphomolybdenum method the extract shows potent anti-oxidant activity. The extract shows significant activity in all three methods. The results are shown in Tables 2-4 and Figures 1-3.

\begin{tabular}{|l|l|}
\hline $\begin{array}{l}\text { Type of Phyto chemical } \\
\text { constituents }\end{array}$ & $\begin{array}{l}\text { Methanolic extract of Euphorbia } \\
\text { thymifolia }\end{array}$ \\
\hline Alkaloid & $+\mathrm{ve}$ \\
\hline Carbohydrates & $+\mathrm{ve}$ \\
\hline Glycosides (Anthraquinone, cardiac) & $+\mathrm{ve}$ \\
\hline Saponin glycosides & $+\mathrm{ve}$ \\
\hline Proteins & $-\mathrm{ve}$ \\
\hline Volatile oils & $-\mathrm{ve}$ \\
\hline Fats and fixed oils & $-\mathrm{ve}$ \\
\hline Steroids & $-\mathrm{ve}$ \\
\hline Flavonoids & $+\mathrm{ve}$ \\
\hline Saponins & $+\mathrm{ve}$ \\
\hline Tannins & $-\mathrm{ve}$ \\
\hline +ve: Indicates the presence of Phytochemical constituents. \\
\hline
\end{tabular}

- ve: Indicates the Absence of Phytochemical constituents.

Table 1: Preliminary phytochemical screening tests.

\begin{tabular}{|l|l|l|l|}
\hline Conc. & Control & Standard & ETM \\
\cline { 3 - 4 } & & Absorbance & Absorbance \\
\hline $10 \mu \mathrm{g}$ & $0.982 \pm 0.01$ & $0.680 \pm 0.03(30.75)$ & $0.355 \pm 0.02(63.84)$ \\
\hline $25 \mu \mathrm{g}$ & $0.982 \pm 0.01$ & $0.696 \pm 0.02(29.12)$ & $0.429 \pm 0.02(56.31)$ \\
\hline $50 \mu \mathrm{g}$ & $0.982 \pm 0.01$ & $0.728 \pm 0.01(25.86)$ & $0.495 \pm 0.03(50.50)$ \\
\hline $75 \mu \mathrm{g}$ & $0.982 \pm 0.01$ & $0.746 \pm 0.01(24.03)$ & $0.532 \pm 0.01(45.82)$ \\
\hline $100 \mu \mathrm{g}$ & $0.982 \pm 0.01$ & $0.792 \pm 0.01(19.34)$ & $0.613 \pm 0.01(37.57)$ \\
\hline
\end{tabular}

Table 2: Anti-oxidant activity of solvent extract of Euphorbia thymifolia linn. using $\mathrm{H}_{2} \mathrm{O}_{2}$-Scavenging Profile Method.

\begin{tabular}{|l|l|l|l|}
\hline Conc. & Control & Standard & ETM \\
\cline { 3 - 4 } & & Absorbance & Absorbance \\
\hline $20 \mu \mathrm{g}$ & $0.776 \pm 0.01$ & $0.530 \pm 0.05(31.70)$ & $0.572 \pm 0.02(26.28)$ \\
\hline $40 \mu \mathrm{g}$ & $0.776 \pm 0.01$ & $0.455 \pm 0.02(41.36)$ & $0.595 \pm 0.01(23.32)$ \\
\hline $60 \mu \mathrm{g}$ & $0.776 \pm 0.01$ & $0.407 \pm 0.02(47.55)$ & $0.603 \pm 0.01(22.29)$ \\
\hline $80 \mu \mathrm{g}$ & $0.776 \pm 0.01$ & $0.242 \pm 0.01(68.81)$ & $0.647 \pm 0.01(16.62)$ \\
\hline $100 \mu \mathrm{g}$ & $0.776 \pm 0.01$ & $0.233 \pm 0.01(69.97)$ & $0.691 \pm 0.01(10.95)$ \\
\hline
\end{tabular}

Table 3: Anti-oxidant activity of solvent extract of Euphorbia thymifolia linn. using reducing power method.

\begin{tabular}{|l|l|l|l|}
\hline Conc. & Control & Standard & ETM \\
\cline { 3 - 4 } & & Absorbance & Absorbance \\
\hline $20 \mu \mathrm{g}$ & $0.882 \pm 0.01$ & $0.580 \pm 0.05(34.24)$ & $0.531 \pm 0.05(39.79)$ \\
\hline $40 \mu \mathrm{g}$ & $0.882 \pm 0.01$ & $0.595 \pm 0.02(32.53)$ & $0.549 \pm 0.04(37.75)$ \\
\hline $60 \mu \mathrm{g}$ & $0.882 \pm 0.01$ & $0.627 \pm 0.02(28.91)$ & $0.639 \pm 0.04(27.55)$ \\
\hline $80 \mu \mathrm{g}$ & $0.882 \pm 0.01$ & $0.634 \pm 0.02(28.11)$ & $0.686 \pm 0.05(22.22)$ \\
\hline $100 \mu \mathrm{g}$ & $0.882 \pm 0.01$ & $0.683 \pm 0.01(22.56)$ & $0.692 \pm 0.06(21.54)$ \\
\hline
\end{tabular}

Table 4: Anti-oxidant activity of solvent extract of Euphorbia thymifolia linn. using Phosphomolybdenum Method. 
Citation: Gurava Reddy K, Anuradha V, Samba Siva Rao V (2017) Phytochemical and Antioxidant Activities of Methanolic Extract of the Plant Euphorbia thymifolia Linn. Nat Prod Chem Res 5: 294. doi:10.4172/2329-6836.1000294

Page 3 of 3

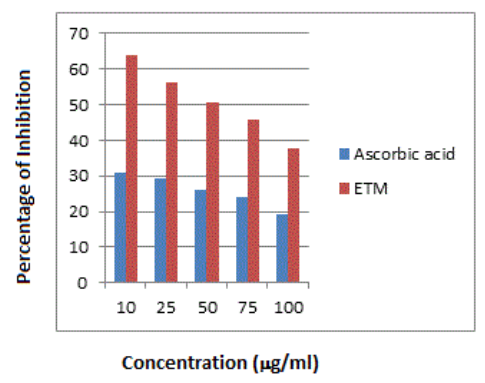

Figure 1: $\mathrm{H}_{2} \mathrm{O}_{2}$ Scavenging method.

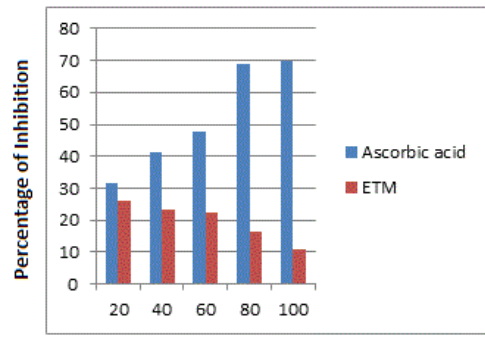

Concentration $(\mu \mathrm{g} / \mathrm{ml})$

Figure 2: Reducing power method.

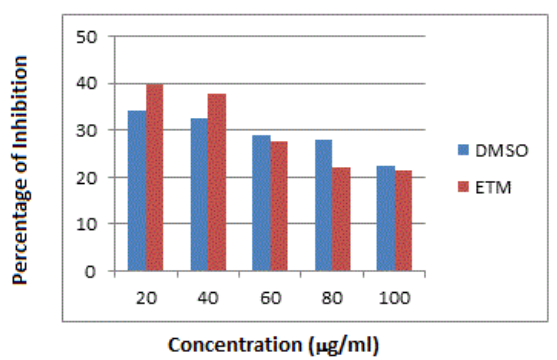

Figure 3: Phosphomolybdenum Method.

\section{References}

1. Jayaveera KN, Yoganandham Reddy K, Govindarajula Y, Kumanan R (2010) Phyto Chemical Screenings, Antibacterial Acitivity and Phyto Chemical Constants of Ethanolic Extract of Euphorbia thymifolia Linn. Int J Pharm Sci 2: 81-82.

2. Kokate CK (2000) Practical Pharmacognosy, constants of ethanolic extract of Euphorbia thymifolia linn. pp: 107-111.

3. Harbone JB, Baxter H (1999) Phytochemical Methods. The handbook of natural flavonoids. Chapman and Hall, London, pp: 60-66.

4. Ruch RJ, Cheng SJ, Klaunig JE (1989) Prevention of cytotoxicity and inhibition of intercellular communication by antioxidant catechins isolated from Chinese green tea carcinogenesis. 10: 1003-1008.

5. Vijaya C, Ramanathan M, Subbaraju T, Suresh B (2002) Correlation of phenolic content and in vitro antioxidant activity of certain herbal extracts. Ind Drug 39: 453-455.

6. Atkinson J, Epand RF, Epand RM (2007) Tocopherols and tocotrienols in membranes: A Critical review. Free Radic Biol Med 44: 739-764.

7. Hernes PJ, Benner R, Cowie GL, Goni MA, Bergamaschi BA, et al. (2001) Tannin diagenesis in mangrove leaves from a tropical estuary: a novel molecular approach. Geochimica Cosmochimica Acta 65: 3109-3122. 